\title{
Success Factors of Entrepreneurs of Small and Medium Sized Enterprises: Evidence from Bangladesh
}

\author{
Mohammed S. Chowdhury \\ Touro College, Department of Business and Accounting, New York \\ E-mail: mchowdr@yahoo.com
}

Zahurul Alam

Department of Management Studies

University of Chittagong, Bangladesh

E-mail: zahurul_cu@yahoo.com

Md. Ifttekhar Arif

Lecturer, Institute of Education Research and Training

University of Chittagong, Bangladesh

Received: June 13, 2013 Accepted: June 30, 2013

doi:10.5296/ber.v3i2.4127 URL: http://dx.doi.org/10.5296/ber.v3i2.4127

\begin{abstract}
In order to assess the factors that affect the success of entrepreneurs of small and medium sized enterprises of Bangladesh, survey data were collected from eighty entrepreneurs from the southern region of Bangladesh selected through random sampling technique. Success factors here refer to demographic characteristics and environmental factors that impede the business success of entrepreneurs of small and medium-sized enterprises of Bangladesh. The results indicate that that the success of the entrepreneurs was correlated to all independent variables in the study and all hypotheses were supported. Lack of infrastructure, sound political environment, access to market and capital were the major factors that positively hindered the success of the entrepreneurs. Experience and education were positively correlated while age was negatively correlated to success. The regression models fit for regression equations were determined by $\mathrm{F}$ statistics. The models indicate positive and statistically significant relationship. Altogether demographic variables explained $26.9 \%$ of the total variance in
\end{abstract}


success while environmental variables explained $39.8 \%$ of the total variance in success.

Keywords: Entrepreneurship, Infrastructure, Environment, Success, Education, Experience

\section{Introduction}

There is a broad consensus that a vibrant SMEs (herein referred to as Small and medium-sized enterprises) sector is one of the principal driving force in the development of a market economy and vital for a healthy economy (Nafukho and Muya, 2010). The men and women who run these enterprises are called entrepreneurs. Entrepreneurship is a company that undertakes new arrangement to produce new products and services ( Schumpeter, 1934). It is a process of innovation and creation with four dimensional elements -individual, organization, environmental factors and process, with support from the government, education, and constitution (Kuratko and Hodgetts, 2004). Historically, it is proven that that with each economic downturn in both developed and developing countries, it is the entrepreneurial drive and persistence that brings us back (Kuratko 2006). In this study, we focus on entrepreneurship as it takes place in SMEs since the two are closely related and cannot be isolated from each other.

Various types of SMEs such as village handicraft makers (weaving, embroidery etc), potteries, dying, small machine shops, restaurants, knitting, small dairy process etc, are, therefore, becoming increasingly important to economic development of developing nations. For example between 1990 and 1995, an average of 84 out of 100 new jobs in the region were generated by micro enterprises in Latin American countries. (Orlando \& Pollock, 2000). In Least Developed Countries (LDCs) in Asia small medium enterprises account for $80 \%$ of the firms generating $80 \%$ employment and $40-70 \%$ of value added and in Bangladesh small medium enterprises account for the majority of firms (87\%) providing $80 \%$ of total employment and contributing 15 percent to Gross Domestic Product (GDP) of the country (Narain, 2003). It is generally recognized that six million SMEs (firms of less than 100 employees) of Bangladesh have a significant role in generating growth and jobs (ADB, 2004). The country's SMEs sector contributed up to $25 \%$ of Bangladesh's gross domestic product, about $40 \%$ of gross manufacturing output, $80 \%$ of industrial jobs, and around $25 \%$ of the total labour force in 2003 (ADB, 2004), making the country's SMEs the largest business sector in the economy of Bangladesh. The garment sector of Bangladesh alone directly employs 2.7 million people, including 1.25 million women and is the source of direct and indirect employment for 10 million people (Levin, 1998 cited in Chowdhury, 2007).

\subsection{Problem Statement}

In Bangladesh, most SMEs operate along traditional lines in production and marketing. There is a growing evidence in literature that the main problem for SMEs in developing countries is not their small size but their isolation, which hinders access to markets, as well as to information, finance and institutional support (Mead \& Liedholm, 1998; Swierczek \& Ha, 2003). A host of factors prevent them from realizing their full potential as entrepreneurs, where they could make significant contribution to society. These factors relate to the characteristics of entrepreneurs, psychological traits, finance, capitalization, marketing, technology, social 
network, gender, government policy issues, and management and performance of the firms. While several of these challenges are in inherent to many countries, some of them are more severe in South Asia, particularly Bangladesh. It is important that factors be identified that affect the business success of the entrepreneurs in this country.

Research has shown that success is closely connected to education level (Staw 1991; Meng and Liang, 1996), experience (Ziemmerer and Scarborough, 1998) and age (Sletten and Hulaas, 1998). Also, numerous studies (Chowdhury, 2007; Larsen and Lewis, 2007; McDowell, 1997; Prahlad, 2004; Mintoo, 2006) have revealed the relationship of entrepreneurial success to environmental factors such as political environment, government, infrastructure, technology etc. Cooper (1985) reported three factors responsible for entrepreneurial development and success at the grass root level. These are antecedent influences (background factors such as family influence, skills and knowledge), the incubator organization (the nature of the organization where the entrepreneurs were employed prior to starting their own business) and environmental factors (e.g., infrastructure, political environment, access to capital, role of government etc).

A closer look into such studies reveals that these environmental and demographic factors in relationship to entrepreneurial success have received scant attention in Bangladesh. Moreover, though the promotion of SMEs development has been a stated objective of successive governments of Bangladesh since 1947, they have not been able to unleash entrepreneurial talents and enhance their success to increase productivity throughout the economy (Chowdhury, 2007).

Built on theories and research on entrepreneurship, this study has attempted to capture the essence of identification of factors affecting the business success of entrepreneurs of small and medium sized enterprises. One of the major impacts of this study is that it will constitute an aid to policy makers, researchers, academia, and the business community as well for improving the performance of entrepreneurs of small and medium sized enterprises in this country. The purpose of this study is, therefore, to determine factors affecting business success of small and medium-scale entrepreneurs in Bangladesh that relate to demographic and environmental variables (see figure 1) from Bangladesh context.

Research Question

To what extent do demographic factors affect business success of entrepreneurs in SMEs sector of Bangladesh?

To what extent do environmental factors affect business success of entrepreneurs in SMEs sector of Bangladesh?

Research Objectives:

To identify demographic factors that affect business success of entrepreneurs in SMEs sector of Bangladesh

To identify the environmental factors that affect business success of entrepreneurs in SMEs sector of Bangladesh 


\section{Macrothink}

Business and Economic Research

ISSN 2162-4860

2013, Vol. 3, No. 2

It is argued that entrepreneurship is environmentally determined phenomenon (see McDowell, 1997, Prahalad, 2004, Quddus and Rashid (2000). Indarti, N and Langenberg, M ( 2005) also reported external environment and demographic factors affecting SME business success. The environmental constraints can make or mar entrepreneurial decision making. This supports the thesis that ability to success is impaired by environmental constraints.

Demographically, age, gender, education, and work experience have been found to have impact on entrepreneurial success. Educated people are creative and innovative and they are always looking for something unique to fill a need or want (Ndubisi et al, 2003). The educated and experienced women are more interested in becoming entrepreneurs than non-educated and inexperienced women (Kavita, Anantharaman, and Jayasingam 2008). People between the age of 25 and 44 are most likely to be involved in entrepreneurial activity ( Reynolds et al, 2000).

These demographic and environmental factors are considered for the theoretical framework of our study based on suitability within Bangladesh context. Accordingly the study of key factors affecting success of entrepreneurs in Bangladesh can be grouped into:

Demographic characteristics

Environmental elements

\subsubsection{Theoretical Framework}

These demographic and environmental factors are considered for the theoretical framework of our study (see figure 1).

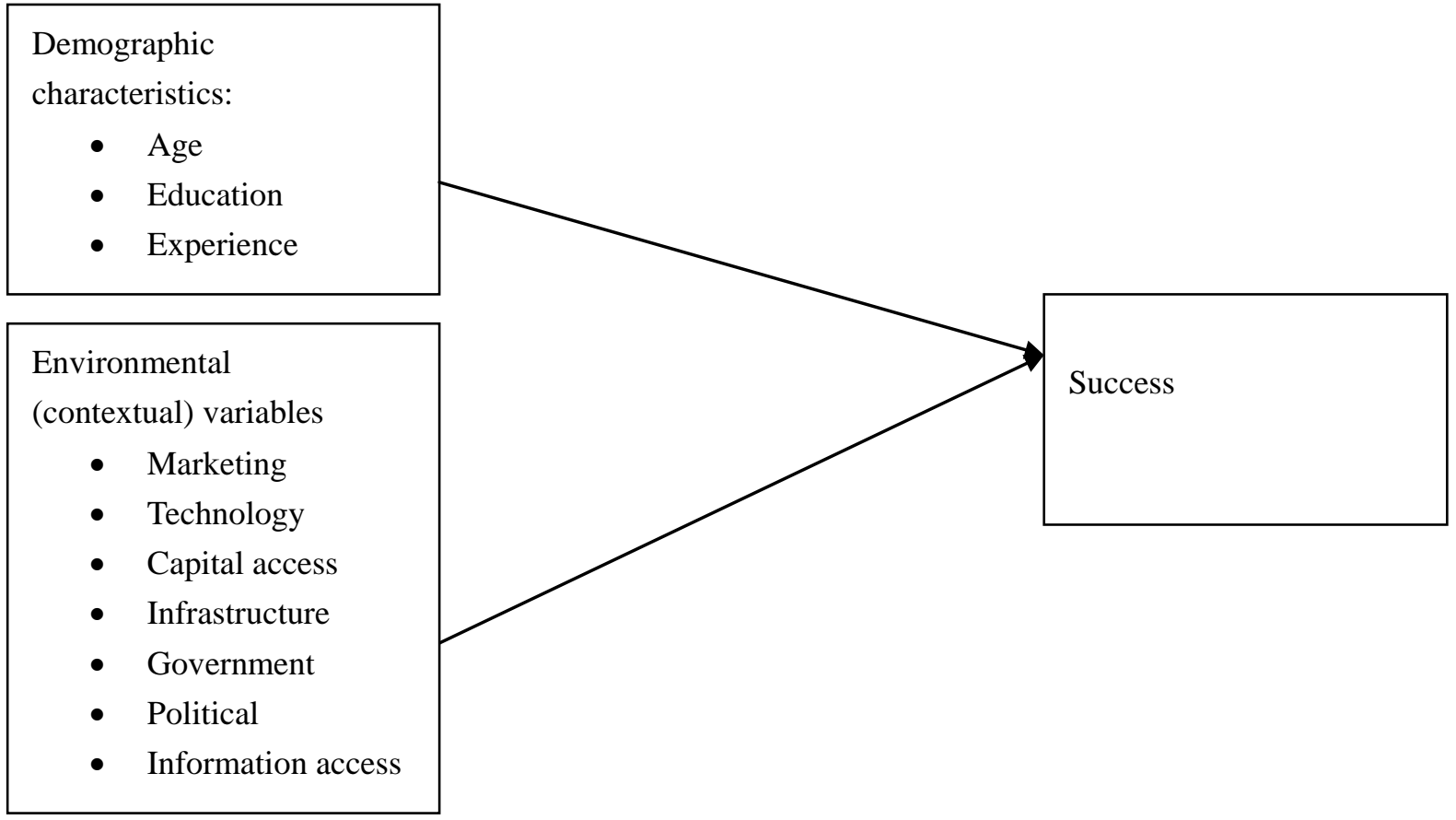

Figure 1. Theoretical Framework 


\section{Literature Review}

\subsection{Business Success of Entrepreneur}

Success refers to the achievement of goals and objectives in any sector of human life. Though, in business, the concept of success generally refers to a firm's financial performance, it has been interpreted in many different ways (Foley and Green, 1989). Some authors defined success from tangible (objective) points of view such as revenue or a firm's growth, personal wealth creation, profitability, turnover (Perren, 2000; Amrit et al 2000). Other studies (Watson et al 1998; Taormina and Lao, 2007) associated entrepreneurial success with continued business operations, operating for at least three years. Some other studies have interpreted the success from intangible points of view where intangible assets (e.g., goodwill of firm) are linked to key factors of success. Despite the fact that success has been widely studied topic in the field of entrepreneurship, no consensus on what is understood by the success of the firm can be found in the literature (Perez and Caninno, 2009). Our contention is that success is largely determined by subjective perceptions of the entrepreneur regarding their success (Ibrahim and Goodwin, 1986). This study, therefore, attempts to find out the relationship of success as perceived by entrepreneurs to demographic and main environmental elements.

\subsubsection{Demographic Characteristics}

A wide range of studies (Muncuso, 1974; Cooper and Dunkelberg, 1987; Dolinsky et al 1993; Gratner, 1989 ) profiling the demographic characteristics of entrepreneurs is evidenced in the literature. A common trend in all of these studies has been the reliance on descriptive profiles of demographic and personal characteristics, which are then often compared with results derived from similar studies in different country settings. We propose, in this study, that education, age and experience are important demographic factors from the context of Bangladesh. The argument is that education and experience play a fundamental role in the process of economic development of a developing country (Scott et al 1998). Future entrepreneurs tend to be younger possessing stronger educational backgrounds and having less previous working experience (Sletten and Hulaas, 1998). Skills and educational backgrounds of these entrepreneurs are vital to the development of new businesses. Secondly, more and more men and women are emerging as entrepreneurs in the economy of Bangladesh with less experience and education (Chowdhury, 2011). Several other studies (Reynolds et al 2000; Kristiansen et al 2003; Sinha, 1996) found a significant relationship between the age of entrepreneur and business success.

Based on the above discussion on demographic characteristics of entrepreneurship proposed in our theoretical framework, we hypothesize the following:

H1: There is a significant relationship between the age of entrepreneurs and business success.

$\mathrm{H} 2$ : There is a significant relationship between education of the entrepreneurs and their success.

H3: There is a significant relationship between work experience of the entrepreneurs and their success 


\subsubsection{Environmental Elements}

A host of environmental factors (see figure 1) impede the success of small business in Bangladesh. For example (Begum, 1993) reports lack of government efforts and incentives. Several studies (Camp and Anderson, 2000; Chowdhury, 2007; McDowell, 1997) report absence of adequate infrastructure facilities. Some study (Quddus and Rashid, 2000) reports myriad of bureaucratic obstacles that entrepreneurs face in their quest to start a business. A host of factors such as lack of long-term capital (Chowdhury and Amin, 2011), limited personal and family savings (Mintoo, 2006), limited access to market (Keh, Nguyen and Ng, 2007; Mead and Liedholm, 1998; Swierczek and Ha, 2003), technology (Gundry, Ben-Yoseph and Posig, 2002; Gibbons and O'Connor, 2003) and information (Singh and Krishna, 1994; Duh, 2003; Kriestiansen, 2002) have been found to be impeding the success of entrepreneurs of small and medium enterprises of Bangladesh. Personal and political enmity between political rivals, frequent haratal (strikes), lack of respect for elementary principles of democratic governance have become the principal characteristics of political system of the country (Chowdhury, 2007). A series of prolonged haratal and labor unrest at garment factories affect the socio-economic and political condition of the country. The average cost of haratal during 1990s to Bangladesh economy was 3 to 4 per cent of GDP of the economy (UNDP, 2005)

The foregoing discussion reveals that the success of entrepreneurs is influenced by environmental factors. The following hypotheses are, therefore, proposed on the environmental variables stated in our theoretical framework.

H4: There is a significant relationship between market and the success of entrepreneurs

H5: There is a significant relationship between government support and the success of entrepreneurs

H6: There is a significant relationship between access to capital and the success of entrepreneurs.

H7: There is a significant relationship between technology and the success of entrepreneurs.

H8: There is significant relationship between information access and the success of entrepreneurs

H9: There is a significant relationship between infrastructures and the success of entrepreneurs

H10: There is a significant relationship between political environment of the country and the success of the entrepreneurs

\section{Materials and Method}

\subsection{Sample}

To achieve the objectives of this study a sample of eighty seven entrepreneurs was conveniently chosen from southern region of Bangladesh. Convenience sampling was employed because of the paucity of statistics on the target group. The questionnaires were distributed to the entrepreneurs and in distributing the questionnaire "drop and collect" procedure was chosen. The questionnaires were collected after a period of 30 days. Eighty 
entrepreneurs filled the questionnaire correctly. Therefore, only eighty entrepreneurs were taken into consideration in the study. Enterprises taken up for the study were food, printing and publication, wooden \& steel furniture, boutiques, beauty parlors, handloom units, and nursing homes. They were all SMEs with twenty or fewer employees. This is generally accepted definition of SMEs for this study ( Ibrahim and Goodwin, 1986). Most entrepreneurs were male (92\%) and a vast majority of them (58\%) had four years college degrees. Majority of them fell in the age group of 31-40.

\subsubsection{Instruments}

The study relied primarily on the survey method. A survey instrument was developed to capture the information relating to the research objectives. A structured questionnaire was distributed to entrepreneurs. The resulting questionnaire comprised of demographic and environmental information of the respondents and a set of items to measure business success.

\subsubsection{Measurement of Variables}

Subjective perceptions of the entrepreneurs regarding their success (dependent variable in this study) have been used in our study rather than objective measures. This is in parallel with previous studies (Perez and Canino, 2009; Wang and Ang, 2004). Subjective measures may also reliably assess the success of business and may become best way to obtain information that would otherwise be very difficult to gather (Perez and Canino, 2009). Five-point Likert scale anchored by strongly disagrees and strongly agrees were applied to measure the perceived success that comprised four items, trapped into one variable.. One typical item was: I consider my business successful. Another item was: I consider my business growing. Cronbach's alpha of the items was .73.

Demographic and Environmental factors are independent variables in this study. As part of capturing demographic information of the respondents, we have included only three demographic characteristics: age, education, and experience. The three factors conform to the suitability of Bangladesh situation. Cronbach's alpha of the items was .71.

In regard to environmental variables, the respondents were asked to score the importance of seven environmental factors on a scale anchored by very unimportant to very important. All these factors relate to external environment that affect success of the entrepreneurs and conforms to previous research (Indarti and Langenberg, 2005; Huggins, 2000) This part consisted of 27 items, trapped into seven variables.

\section{Results}

\subsection{Validity and Reliability of the Instrument}

Table 1. Reliability test

\begin{tabular}{|l|l|l|l|}
\hline No & Variable & No of items & Cronbach's alpha \\
\hline 1 & Marketing & 5 & 0.78 \\
\hline 2 & Technology & 4 & 0.73 \\
\hline 3 & Information access & 3 & 0.69 \\
\hline
\end{tabular}




\begin{tabular}{|l|l|l|l|}
\hline 4 & Capital access & 5 & 0.81 \\
\hline 5 & Government support & 3 & 0.67 \\
\hline 6 & Political environment & 4 & 0.71 \\
\hline 7 & Infrastructure & 3 & 0.68 \\
\hline
\end{tabular}

As seen in the table labove each variable consisted of at least 4 items. The values of Cronbach's alpha are greater than 0.6 for each variable and hence considered acceptable ( Nunally, 1978). We conclude that the research instrument used in the study is valid and reliable.

\subsubsection{Data Analysis}

To analyze data, descriptive statistics, correlation and regression analyses were used. Pearson $r$ is the most widely used bivariate correlation technique (Gall and Gall, 1996). Pearson's correlation measures both direction and extent of association between the variables. The coefficient of correlation measure was, therefore, used to examine the relationship between the success and demographic factors and between success and environmental factors. Two regression equations were used to test our theoretical model. One for analyzing the direct effects of seven environmental variables on success and another for doing the same for demographic variables, aimed at determining the highest influence factor (s) of independent variables on business success of entrepreneurs.

Table 2 presents correlation between success and demographic characteristics. Table 2 indicates that experience and education are positively correlated while age is negatively correlated to business success.

Table 2. Correlation between success and demographic characteristics

\begin{tabular}{|l|l|l|l|l|}
\hline & Success & Age & Education & Experience \\
\hline Success & 1 & $-.241^{*}$ & $.255^{*}$ & $.249^{*}$ \\
\hline Age & -.2418 & 1 & .212 & -.237 \\
\hline Experience & $.255^{*}$ & -.212 & 1 & $-.322^{*}$ \\
\hline Education & $.249 *$ & -.237 & $-.322 * *$ & 1 \\
\hline
\end{tabular}

**Correlation is significant at the .01 level $(2$-tailed $)$

*Correlation is significant at the .05 level ( 2 tailed)

Regression analysis results (see table 3) based on independent variables (demographic) depicts that education and experience directly affect the success of entrepreneurs in Bangladesh, as evidenced from greater $t$-value $(t>2)$. Age factor has relatively less and negative influence on success when compared to these two factors $(\mathrm{t}=-1.93)$. Altogether demographic variables explained $26.9 \%$ of the total variance (adjusted r-square is .269). 


\section{Macrothink}

Business and Economic Research

ISSN 2162-4860

2013, Vol. 3, No. 2

Table 3. Coefficient of determination between independent variables (demographic) and dependent variable

\begin{tabular}{|l|l|l|l|l|l|}
\hline Variable & Beta Standard coefficient & T-value & Significance & Mean & SD \\
\hline Success & & 6.41 & 000 & 4.7 & .6825 \\
\hline Age & -2.00 & -1.938 & .056 & 37. & 6.301 \\
\hline Experience & .293 & 2.868 & .000 & 2.5 & .5031 \\
\hline Education & .348 & 3.329 & .000 & 2.0 & .5624 \\
\hline
\end{tabular}

Model summary:

Adjusted R-square .269

F 8.259

As regards to environmental variables, results (table 4) show that all the independent variables are correlated to the entrepreneurial success.

Table 4. Inter-correlation between environmental variables and entrepreneurial success

\begin{tabular}{|l|l|l|l|l|l|l|l|l|}
\hline & Success & Mkt & Capital & Infra & Govt & Tech & Polenv & Info \\
\hline Success & 1 & $.435^{* *}$ & $.256^{*}$ & $.447^{* *}$ & $.288^{* *}$ & $.328^{* *}$ & $.406^{* *}$ & $.225^{*}$ \\
\hline Mkt & $.435^{* *}$ & 1 & -.073 & $.573^{* *}$ & $.285^{*}$ & $.283^{*}$ & .161 & $.277^{*}$ \\
\hline Capital & $.256^{*}$ & -.073 & 1 & -.064 & .204 & .020 & .018 & .165 \\
\hline Infra & $.447^{* *}$ & $.573^{* *}$ & -.064 & 1 & $.401^{* *}$ & $.314^{* *}$ & .152 & $.352^{* *}$ \\
\hline Govt & $.288^{* *}$ & $.285^{*}$ & .204 & $.401^{* *}$ & 1 & $.475^{* *}$ & .106 & $.305^{* *}$ \\
\hline Tech & $.328^{* *}$ & $.283^{*}$ & .020 & $.314^{* *}$ & $.475^{* *}$ & 1 & .146 & $.396^{* *}$ \\
\hline Politcal & $.406^{* *}$ & .161 & .018 & .152 & .106 & .146 & 1 & -.014 \\
\hline Info & $.225^{*}$ & $.277^{*}$ & .165 & $.352^{* *}$ & $.305^{* *}$ & $.396^{* *}$ & -.014 & 1 \\
\hline
\end{tabular}

**Correaltion is significant at the .01 level ( 2 tailed)

* Correlation is significant at the .05 level ( 2 tailed)

Notes: $* \mathrm{p}<0.1, * * \mathrm{p}<0.05$

Mkt= Marketing, Infra $=$ Infrastructure

Govt $=$ Government $;$ Info $=$ Information access

Polenv= Political environment

Regression analysis results based on independent variables (environmental) show that (see table 5) market, infrastructure, capital access, political environment, affected entrepreneurial success significantly in positive directions as proved by the higher $\mathrm{t}(\mathrm{t}>2)$ and beta for each of them. Altogether, the independent variables (environmental) explained $39.8 \%$ of the total variance in success (adjusted R-square is .398) 
Table 5. Coefficient of determination between independent variables (environmental) and dependent variables

\begin{tabular}{|l|l|l|l|l|l|}
\hline Variable & Beta standard coefficient & T-value & Significance & Mean & Standard Deviation \\
\hline Success & & -4.19 & .000 & 11.45 & 3.84 \\
\hline Marketing & $2.134 * *$ & 2.134 & .036 & 12.75 & 2.37 \\
\hline Capital access & $.294 * * *$ & 3.177 & .000 & 13.96 & 1.22 \\
\hline Infrastructure & $.263 * *$ & 2.285 & .025 & 12.56 & 3.43 \\
\hline Government support & -.044 & -.406 & .686 & 8.42 & 4.66 \\
\hline Technology & .161 & 1.514 & .134 & 7.11 & 4.24 \\
\hline Political environment & $.304 * * *$ & 3.386 & .000 & 4.88 & .389 \\
\hline Information access & -.027 & -.262 & .794 & 11.62 & 3.64 \\
\hline
\end{tabular}

$* * \mathrm{p}<0.05, * * * \mathrm{p}<0.001$

$$
\begin{aligned}
& \text { Model summary: } \\
& \text { Adjusted R-square } \\
& \text {.398: F value } 8.448 \text { : } \\
& \text { Significance } 000
\end{aligned}
$$

\section{Discussion}

The main objective of this study has been to present a general model toward understanding the dynamics of entrepreneurial success. We have developed the framework that included demographic and environmental factors (see figure 1). The study supports the contention that age, education and experience affect the success of entrepreneurs in Bangladesh. Several studies (Scott, Rosa and Klandt, 1998; Reynolds et al 2000; Kriestiansen et al , 2003; Sinha, 1996) support this contention of our study. The study reveals that supportive environmental factors may well be linked with the success of the entrepreneurs in Bangladesh. This study clearly supports that volatile political environment, lack of access to capital, lack of infrastructure and technology are the major constraints limiting the success of entrepreneurs in Bangladesh. Entrepreneurs in all parts of the world seem to have a problem accessing capital, securing financing, convincing bankers and obtaining bank loans or credit from suppliers. This conforms to several studies around the world that have been carried out to throw light on the challenges faced by entrepreneurs. For example, in South Asia, lack of access to capital has been a primary obstacle for entrepreneurs, and recent research suggests it continues to be" (Gundry, Ben-Yoseph and Posig, 2002). This could also include start-up financing and credit, cash flow management in the early operations and financial planning. Research suggests that the primary source of funding has been through family loans, personal savings, credit cards, and home equity loans (Gundry, Ben-Yoseph and Posig, 2002).

\section{Conclusion and Future Research}

The challenges towards success of entrepreneurs of small and medium size enterprises have depicted several key issues, relating to demographic and environmental factors. Despite many barriers to success, a new entrepreneur class has arisen in the country taking on the challenge to work in a competitive and complex economic and business environment. Not only 
have their entrepreneurship improved their living conditions and earned more respect in the family and the society, but they are also contributing to business and export growth, supplies, employment generation, productivity and skills development of the country. Therefore, there is a need for a continuous and coherent focus on financing, advisory and work life balance for enhancing entrepreneurship in Bangladesh. The country needs a frame for policy learning in order to develop a proper policy mix towards promoting entrepreneurship.

A favorable political and economic climate is a pre-condition for the development of any business in any country in this world. The entrepreneurs of Bangladesh must be recognized as an important unit contributing to the economic growth of the country since small and medium business sector is going to attract and create jobs for many more Bangladeshis. They must be supported by the governmental organizations and their constraints must be recognized and a structured and organized strategic plan put in place to help them overcome these limiting factors. Bangladesh Government must come forward to enhance the entrepreneurial capabilities of entrepreneurs through funding and skill development.

\section{Future Research}

The study has been able to explore a number of issues that require further investigation. Future research should seek to investigate into the factors other than demographic and environmental factors (e.g., entrepreneurs' innovative behavior, personality traits) that affect the success and growth of entrepreneurship in the country. Longitudinal data may reveal a trend in constraints to entrepreneurship success that this study was not able to uncover. Such study will provide a clearer picture of the antecedent's influence on entrepreneurial success. A combination of survey and case study methods should be employed. The findings of such a study should assist various actors to focus their efforts on the growth and success factors of SME sector of Bangladesh.

\section{References}

Amit, R., MacCrimmon, K., Zietsman, C., \& Oesch, J (2000). Does money matter? Wealth attainment as the motive for initiating growth-oriented technology ventures. Journal of Business Venturing, 16(2), 119-143. http://dx.doi.org/10.1016/S0883-9026(99)00044-0

Asian Development Bank (2004). ADB to help foster development of SME sector in Bangladesh. Available at ADB.Org.

Begum, R. (1993). Entrepreneurship in small industries: a case study of engineering units", Dhaka University Journal of Business Studies, 14(1), 159-168

Camp and Anderson (2000), Telecommunication Regulation in Bangladesh: A Broad Band future Through Development Initiative, Electronic proceedings of ISOC. www. ISOC. ORG/ INET

Chowdhury, M, \& Amin, M. ( 2011). The effects of human, social and financial capital on woman entrepreneurship venturing in Bangladesh, International Journal of Business and Economics Perspectives, 6(1), 138-149. 


\section{Al Macrothink}

Business and Economic Research ISSN 2162-4860 2013, Vol. 3, No. 2

Chowdhury, M. (2007). Overcoming entrepreneurship development constraints: the case of Bangladesh. Journal of Enterprising Communities, 1(3), 240-251, Emerald

Chowdhury, M. (2011). Emerging women entrepreneurs in Bangladesh, The daily Starr, April Cooper, .C. (1985). The Role of Incubator Organizations in Funding of Growth Oriented Firms. Journal of Business Venturing, 1(1). http://dx.doi.org/10.1016/0883-9026(85)90008-4

Cooper, A, \& Dunkelberg, W (1987). Entrepreneurial research: old questions, new answers, and methodological issues. American Journal of Small Business, 11(3), 11-23

Dolinsky, L, Caputo, R, Pasumarty, \& K Quazi, H. (1993). The effects of education on business ownership: a longitudinal study of women, Entrepreneurship Theory and Practice, 18(1), $43-53$

Duh, M. (2003). Family enterprises as an important factor of the economic Development: the case of Slovenia. Journal of Enterprising Culture, 11(2), 111-130. http://dx.doi.org/10.1142/S021849580300007X

Foley, P, \& Green, H. (1989). Small Business Success. London, England: Paul Chapman Publishing

Gall, M, Borg, W, \& Gall, J. (1996). Educational research: An introduction, (6th ed). White Plains, NY: Longman Publishers.

Gibbons, T., \& O'Connor, T. (2003). Strategic posture, technology strategy and performance among small firms. Journal of Enterprising Culture, 11(2), 131-146. http://dx.doi.org/10.1142/S0218495803000081

Gratner, B. (1989). Some suggestions for research on entrepreneurial traits and characteristics. Entrepreneurship Theory and Practice, 26, 33-49

Gundry. L. K., Ben-Yoseph. M., \& Posig. M. (2002). Contemporary Perspectives on Women's Entrepreneurship: A Review and Strategic Recommendations. Journal of Enterprising Culture. 10(1), 67-86. http://dx.doi.org/10.1142/S0218495802000141

Huggins, R. (2000). The success and failure of policy-implanted inter-firm network initiatives: motivations, process and structure. Entrepreneurship and Regional Development, 12(2), 211-236. http://dx.doi.org/10.1080/089856200283036

Ibrahim, A, \& Goodwin, J (1986). Perceived causes of success in small business. American Journal of Small Business, 11(2), 41-50

Indarti, N., \& Langenberg, M (2005). Factors Affecting Business Success Among SMEs: Empirical from Indonesia.(available at ww.utwente.nl/nikos/archief/research/conferences/esu/papers/indartilangenber

Kavitha, R, Anantharaman, R, \& Jayasingam, S. (2008). Motivational Factors Affecting Entrepreneurial Decision: A Comparison between Malaysian Women Entrepreneurs and Women Non Entrepreneurs, Communications of the IBIMA, Volume 8 
Keh, T., Nguyen, M., \& Ng, P. (2007). The effectas of entrepreneurial orientation and marketing information on the performance of SMEs, Journal of Business Venturing, 22(4) PP 592-611

Kristiansen, S. (2002). Competition and Knowledge in Javanese Rural Business. Singapore Journal of Tropical Geography, 23(1), 52-70. http://dx.doi.org/10.1111/1467-9493.00118

Kristiansen, S., Furuholt, B., \& Wahid, F. (2003). Internet cafe entrepreneurs: pioneers in information dissemination in Indonesia. The International Journal of Entrepreneurship and Innovation, 4(4), 251-263. http://dx.doi.org/10.5367/000000003129574315

Kuratko, \& Hodgetts. (2004), Entrepreneurship: Theory and Practice. Thomson, Southwestern: New York

Kuratko, D, (2006). A Tribute to 50 years of Excellence in Entrepreneurship and Small Business. Journal of Small Business Management, 44(3), 483-492 http://dx.doi.org/10.1111/j.1540-627X.2006.00185.x

Larsen, P and Lewis, A (2007). How award-winning SMEs manage the barriers to innovation. $\begin{array}{llll}\text { Creativity and Innovation } \quad \text { Management, } & 16(2),\end{array}$ http://dx.doi.org/10.1111/j.1540-627X.2006.00185.x

McDowell, S. D. (1997). Globalization, Liberalization and Policy Change: A Political Economy of India's Communication Sector. New York: St. Martin Press http://dx.doi.org/10.1057/9780230374638

Mead, D., \& Liedholm, C. (1998). The dynamics of micro and small enterprises in developing countries. World Development, $\quad$ 61-74. http://dx.doi.org/10.1016/S0305-750X(97)10010-9

Meng, A, \& Liang, W. (1996), Entrepreneurs, entrepreneurship and enterprising cultures. Paris: Addison-Wesley

Mintoo, A. A. (2006), SMEs in Bangladesh, CACCI Journal, 1(1), 2006.

Muncuso, R. (1974). What it takes to be an entrepreneur: A questionnaire approach. Journal of Small Business management, 12(4), 16-22

Nafukho, M, \& Muya, H. (2010) Entrepreneurship and socio-economic development in Africa: a reality or myth? Journal of European Industrial Training, 34(2), 196-209. http://dx.doi.org/10.1108/03090591011023961

Narain, S (2003). Institution Capacity Building for Small and Medium -Sized Enterprise Promotion and Development. Investment Promotion and Enterprise Development Bulletin for Asia and the Pacific, number \#2, U.N. May.

Ndubisi, O, Gupta, K, \& Massoud, S. (2003). Organizational Learning and Vendor Support Quality By The Usage of Application Software Packages: A Study of Asian Entrepreneurs. Journal of Systems Science and Systems Engineering 12(3), 314-331. http://dx.doi.org/10.1108/03090591011023961 
Nunally, C (1978) . Psychometric Theory. New York: McGraw Hill

Orlando, M, \& Pollock, M. (2000). Micro Enterprises and Poverty: Evidence from Latin America. Inter-American Development Bank, Washington D.C.

Perez, E, \& Canino, R. (2009). The importance of Entrepreneur's perception of success. Review Of International Comparative Management, 10(5), 990-1010

Perren, L (2000). Factors in the growth of micro-enterprises: Exploring the implications. Journal of Small Business and Enterprise Development, 7(1) 58-68. http://dx.doi.org/10.1108/EUM0000000006805

Prahald, K. (2004), The fortune at the Bottom of the Pyramid: Eradicating poverty through profits, Wharton School Publishing, University of Pennsylvania, Philadelphia, P.A.

Quddus, M, \& Rashid, S. (2000), Entrepreneurship and Economic Development: The Remarkable Story of Garment Exports from Bangladesh, The University Press Limited, Dhaka

Reynolds, P. D., Hay, M., Bygrave, W. D., Camp, S. M., \& Autio, E. (2000). Global Entrepreneurship Monitor 2000 Executive Report: Babson College, Kaufm an Center for Entrepreneurial Leadership, and London Business School.

Schumpeter, J. (1934). The Theory of Economic Development, Harvard University Press, CCambridge, MA

Scott, M, Rosa, P, \& Klandt, H (1998). Educating entrepreneurs for wealth creation. Brookfield, Vermont: Ashgate Publishing Company.

Singh, A., \& Krishna, M. (1994). Agricultural Entrepreneurship: The Concept and Evidence. Journal of Entrepreneurship, 3(1), 97-111. http://dx.doi.org/10.1177/097135579400300106

Sinha, T. (1996). Human Factors in Entrepreneurship Effectiveness. The Journal of Entrepreneurship, 5(1), 23-39. http://dx.doi.org/10.1177/097135579600500102

Sletten, J., \& Hulaas, H (1998). What and how should entrepreneurs be taught? Implications of different backgrounds and business goals. In M. Scott, P.Rosa and H. Klandt (Ed), Educating entrepreneurs for wealth creation (pp. 169-185). Brrokfield, VT; Ashgate Publishing Company.

Staw, M (1991) Psychological dimensions of organization behavior. Sydney,: McMillan

Swierczek, F. W., \& Ha, T. T. (2003). Entrepreneurial orientation, uncertainty avoidance and firm performance: an analysis of Thai and Vietnamese SMEs. International Journal of Entrepreneurship and Innovation, 46-58. http://dx.doi.org/10.5367/000000003101299393

Taormina, J, \& Lao, S. K M. (2007) Measuring Chinese entrepreneurial motivation: Personality and environmental influences, International Journal of Entrepreneurial Behavior and Research, 13(4), 200-221. http://dx.doi.org/10.1108/13552550710759997

United Nations Development Report (2005), The Cost of Haratal (Strikes) In Bangladesh, The New Age, Dhaka, March 11. 


\section{Macrothink}

Business and Economic Research ISSN 2162-4860 2013, Vol. 3, No. 2

Wang, C, \& Ang, L. (2004). Determinants of Venture performance in Singapore. Journal of Business management, 42(4), 347-363

Watson, K., Hogarth-Scott, S., \& Wilson, N. (1998). Small business start-ups: Success factors and support implication. Journal of Entrepreneurial Behavior and Research, 4(3), 217-238. http://dx.doi.org/10.1108/13552559810235510

Zimmerer, W, \& Scarborough, M. (1998). Essentials of entrepreneurship and business management ( 2nd ed): New York: Prentice Hall

\section{Copyright Disclaimer}

Copyright reserved by the author(s).

This article is an open-access article distributed under the terms and conditions of the Creative Commons Attribution license (http://creativecommons.org/licenses/by/3.0/). 